\title{
KEPEMIMPINAN KEPALA SEKOLAH \\ ( Studi Kasus SMK Islamic Center Nahdlatul Wathan Batam)
}

\section{THE HEAD MASTER LEADERSHIP (Case Study SMK Islamic Center Nahdlatul Wathan In Batam)}

\author{
Nasruji $^{1)}$ \\ Program Studi Pendidikan Sejarah, Fakultas Keguruan dan Ilmu Pendidikan, \\ Universitas Riau Kepulauan, Batam, Kepulauan Riau, Indonesia \\ nasrujisaifulhaq@yahoo.co.id ${ }^{1)}$
}

\begin{abstract}
Abstrak
Kepala Sekolah SMK-IC-NW di Kota Batam, berangkat dari visi kepemimpinan, maka dengan ini cukup jelas karena kepemimpinan pada dasarnya sebuah proses mempengaruhi orang lain dengan kemampuan: berpikir realistis, komunikasi organisasi, pengambilan keputusan dan pemberian penghargaan, langkah tersebut adalah bagain dari kretivitas inovatif meningkatkan motivasi kerja dalam rangka menciptakan jaringan pengembangan organisasi yang ideal. Penelitian ini menggunakan pendekatan kualitatif studi kasus, yaitu penelitian yang bermaksud memahami fenomena tentang apa yang dialami oleh subjek penelitian, misalnya perilaku, persepsi, motivasi, tindakan secara holistik, dan dengan cara deskripsi dalam bentuk kata-kata dan bahasa pada suatu konteks khusus yang alamiah.
\end{abstract}

Kata Kunci: Kepemimpinan Kepala Sekolah SMK-IC-NW

\begin{abstract}
The head master of SMK IC NW in Batam's City, is beginning from leadership vision, the refore it was clearly explain that if the leadership is basica of a process to influence others with the specially competence: think realistic, organisational communication, decision making and appreciation, that steps are part of the creativity thingking to increase the motivation on job in order to make an ideal organisational development network. This research use the qualitative approach by case study, which is research which intentionally understand phenomena that was underground by the research subject. For example is behaviour, perception, motivation, holistik's action, and using the description form of words and language at one particular artless special context.
\end{abstract}

Keyword : The Head Master Leadership SMK - IC - NW'S, and Qualitative

\section{PENDAHULUAN}

Pendididkan merupakan kebutuhan hidup manusia dari zaman ke zaman, dengan pendidikan menjadi cerdas menyikapan berbagai persoalan hidup, sehingga kita sebagai anak bangsa Indonesia akan selalu berpacu meningkatkan jenjang atau kualipikasi pendidikan sebagai upaya mewujudkan cita-cita bangsa yang merdeka dan berdaulat. Indonesia mengembangkan lembaga pendidikan berbentuk formal, noformal, dan informal yaitu sekolah baik negeri, swasta maupun sekolah bertaraf internasional, persaingan sekolah baik negeri maupun swasta selalu terjadi, sekolah negeri mendapatkan bantuan pemerintah dalam pembiayan operasional sekolah termasuk pengadaan sarana dan prasarana, sedangakan sekolah swasta dengan kemampuan yayasan masing-masing terus berusaha untuk meningkatkan kualitas pendidikan sekolahnya, sementara pemerintah terus mendorong perkembangan kualitas sekolah dengan berbagai cara termasuk menaikkan anggaran negara untuk pendidikan saat terjadi kesenjangan yang menjadi issue kritis sistem pendidikan nasioanal.

Sekolah Menengah Kejuruan Islamic Center Nahdlatul Watahan (SMK-IC-NW) berdiri tahun 2008, dengan siwanya berasal dari Kota Batam dan juga dari pulau-pulau sekirtar Batam. Dari semenjak berdirinya SMK-IC-NW tersebut berjalan tidak mestinya yang diharapkan karena, beberapa faktor yang menjadikan pendidikan tersebut kurang diminati sehingga perkembangannnya tidak sesuai dengan lama berdirinya, maka dengan itu peneliti terpanggil ada ketertarikan ingin mendalami kasus yang terjadi pada sekolah tersebut. Saat ini jumlah siswa 17 
orang terdiri dari kelas sepuluh 7 orang, kelas sebelas 6 orang, dan kelas duabelas 4 orang. Sekolah tersebur bernaung di bawah Yayasan Islamaic Center Nahdlatul Wathan Batam.

Pendididkan yang berkualitas dipicu oleh kemampuan manajemrial yang tangguh yaitu manajemrial yang kuat pula, memiliki kemampuan berkomunikasi dalam organisasi dengan baik, bertingkah laku kaya denan nilai-nilai kesopannan dengan tujuan agar kenyamanan terhdap orang lain. Disamping itu juga dalam kepemimpinan disebuah organisasi dituntut bersikap kooperatif dalam mengambil keputusan, memberikan penghargaan kepada bawahan, sehingga mampu meningkatkan mutu pendidikan, bersaing di tengah persaingan global yang kompleks dan modern.

\section{METODE}

Pada penelitian ini menggunakan metode studi kasus dengan sumber data dari kepala sekolah, guru, karyawan, serta siswa SMK-IC-NW yang menjadi informan kunci, dari sebuah proses perkembangan kemajuan sekolah tersebut. Teknik wawancara, observasi partisipan dan analisa dokumen yang dilaksanakan digunakan sebagai prosedur pengumpulan data. Adapun sebagai upaya pencarian kevalidan dalam data yang diangkat, peneliti melakukan trianggualasi, dengan teknik pengumpulan data dan sumber data, dan kegunaan data tersebut akan menjadi acuan reduksi untuk menunjukkan keabsahan data.

Sukmadinata mengemukakan bahwa ada delapan karakteristik penelitian kualitatif, yaitu; (1) kajiannya bersifat naturalistic, melihat situasi apa adanya, (2) analisis yang bersifat induktif, mengungkapkan data khusus, detil untuk menemukan kategori, dimensi, hubungan penting dan asli dengan pertanyaan terbuka, (3) bersifat holistic, keseluruhan fenomena dipahami secara totalitas, (4) data kualitatif, deskripsi rinci dan dalam, persepsi pengalaman orang, (5) hubungan dan persepsi pribadi, terjadi hubungan akrab penelitian dengan informan, (6) dinamis, perubahan terjadi terus sehingga proses desainnya fleksibel, (7) orientasi keunikan dalam setiap situasi khas, (8) empati netral dalam pengertian subjektif murni.

Menurut Miles dan Huberman yang dikutip Sugiyono mengatakan bahwa aktivitas dalam analisis data kualitatif dilakukan secara interaktif dan berlangsung secara terus menerus sampai tuntas, sehingga datanya sudah jenuh. Aktivitas dalam analisis data, yaitu reduksi data (reduction data), penyajian data (display data), dan verifikasi/menggambarkan konklusi (conclusion drawing/verification).

Model interaktif dalam analisis data:

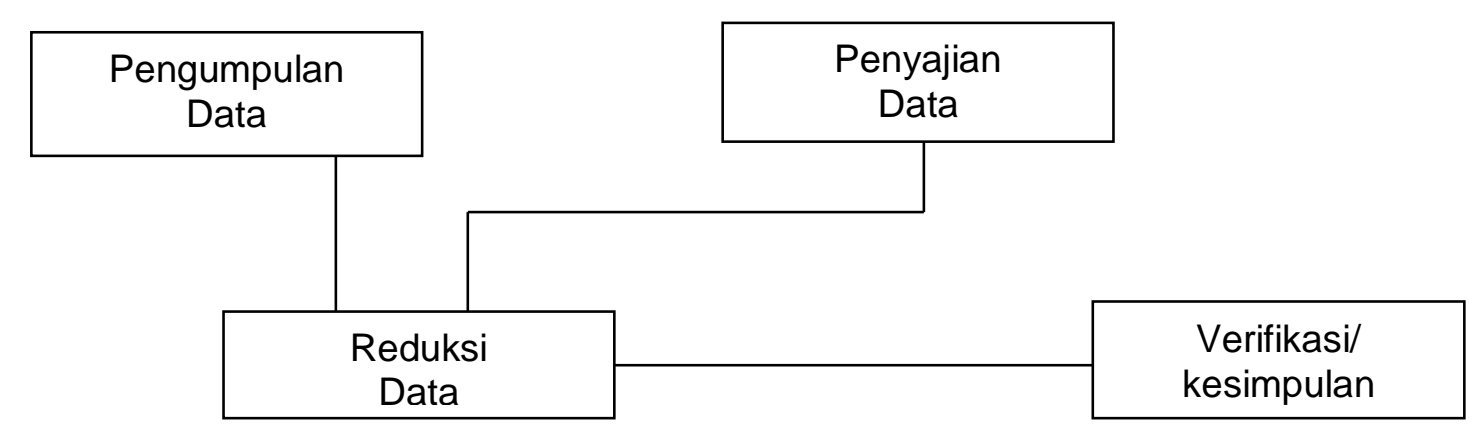

Tabel: Teknik Pemeriksaan Keabsahan Data 


\begin{tabular}{|l|l|}
\hline \multicolumn{1}{|c|}{ KRITERIA } & \multicolumn{1}{|c|}{ TEKNIK PEMERIKSAAN } \\
\hline & 1. Perpanjangan keikutsertaan \\
Kredibilitas (derajat kepercayaan) & 2. Ketekunan pengamatan \\
& 3. Triangulasi \\
& 4. Pengecekan sejawat \\
& 5. Kecukupan referensial \\
\hline Kepastian / keteralihan(transferability) & 6. Kajian kasus negatif \\
\hline Kebergantungan (dependability) & 7. Pengecekan anggota \\
\hline Kepastian (confirmability) & 9. Audit kebergantungan rinci \\
\hline
\end{tabular}

Konsep kepemimpinan yang bersumber pada kekuasaan dalam satu kelompok atau organisasi, bahwa setiap orang atau yang memiliki akses terhadap sumber kekuasaan dalam suatu kelompok atau organisasi tertentu akan mengendalikan atau memimpin kelompok atau organisasi itu dengan terarah yang didukung oleh kedudukan, kepribadian, dan nilai strategi untuk memenuhi sebuah kekuasaan yang kaya potensi kepemimpinannya yaitu: (a) kecerdasan intlektual; (b) kecerdasan emosional; dan (c) kecerdasan spritual. Jika ketiga potensi ini dikembangkan oleh pemimpin, maka apa saja yang direncanakan dalam menjalankan berbagai aktivitas akan berhasil dengan baik.

Konsep kepemimpinan diperkuat pendapat Dewett (2010.14) "Leadership used to mean as the ability to achieve great personal and organizational results through others using positive interpersonal relationships" Jika diterjemahkan secara bebas berarti kepemimpinan adalah kemampuan mencapai tujuan-tujuan personal maupun organisasional yang besar melalui pihak lain dengan menggunakan hubungan interpersonal yang positif.

Selanjutnya ditegaskan Armstrong (2009:04) leadership as "the process of getting people to do their best to achieve a desired result". It involves developing and communicating a vision for the future, motivating people and gaining their engagement, yakni kepemimpinan mencakup menentukan tujuan organisasi, memotivasi perilaku pengikut untuk mencapai tujuan, memengaruhi dan memperbaiki kelompok dan budayanya. Teori kepemimpinan secara umum dapat digolongkan ke dalam empat katagori besar, yaitu menggunakan pendekatan (a) kekuasaan, (b) bakat, (c) perilaku, dan (d) situasi. Batasan ini menegaskan bahwa kepemimpinan merupakan proses membuat orang-orang menggunakan kemampuan terbaiknya untuk mencapai hasil yang diinginkan. Termasuk di dalamnya dengan mengembangkan dan mengkomunikasikan visi masa depan, memotivasi orang lain dan menarik keuntungan dari keterlibatan serta potensi pada mereka.

Kepemimpinan berasal dari kata pimpin yang memuat dua hal pokok yaitu: pemimpin sebagai subjek dan yang dipimpin sebagai objek. Artinya kepemimpinan merupakan kegiatan manusia secara bersama-sama selalu membutuhkan kepemimpinan terencana, sistematis dan terintegrasi dalam semua lini. Kepemimpinan seseorang tergantung pada interaksi yang terjadi antara pemimpin dan pengikutnya, efektivitas kepemimpinan seseorang mengiringi gaya 
kepemimpinan yang tepat untuk menghadapi situasi tertentu dan tingkat kematangan berpikir pengikut.

Disamping itu juga ditegaskan oleh Dubrin (2009:04) sebagai berikut: Kepemimpinan, seperti halnya cinta, dapat dijelaskan dengan banyak cara. Berikut ini ada beberapa definisi untuk memahami apa itu berpikir layaknya seorang pemimpin yaitu: (a) kepemimpinan merupakan upaya mempengaruhi banyak orang melalui komunikasi untuk mencapai tujuan; (b) kepemimpinan adalah cara mempengaruhi orang dengan petunjuk atau perintah; (c) kepemimpinan merupakan tindakan yang menyebabkan orang lain bertindak atau merespon dan menimbulkan perubahan positif; (d) kepemimpinan merupakan kekuatan dinas penting yang memotivasi dan yang mengkoordinasikan organisasi dalam rangka mencapai tujuan; (e) kepemimpinan adalah kemampuan untuk menciptakan rasa percaya diri dan dukungan diantara bawahan agar tujuan organisasional dapat tercapai.

Pemimpin yang ideal jika memiliki kemampuan berbahasa santun atau komunikatif dalam menjalankan tugasnya, hal ini Nelsen (2006:02), bahwa komunikasi dapat diartikan sebagai menyebarkan nilai atau makna-makna yang umum kepada orang lain: (1) teori proses pesan yang terfokus pada begaimana orang-orang menyampaikan, menginterpretasi yang merupakan mensikronisasikan antara perilaku pemimpin mengarah kepada mengevaluasi komunikasi mereka terhadap perilaku orang lain; (2) teori produksi pesan yang terfokus pada bagaimana orang-orang memahami dan melaksanakan perilaku komunikasi dalam rangka intraksi tujuan.

Adapun terkait dengan teori kepemimpinan tersebut di atas juga di pertegaskan oleh Greene (2003:10) menafsirkan bahwa kepemimpinan merupakan suatu tindakan yang mebutuhakan keterapilan dan nialai-nilai kindahan seperti halnya cinta yang dapat dijelaskan dengan banyak cara yaitu: a) kepemimpinan berupaya untuk mempengaruhi banyak orang melalui kecakapan komunikasi yang baik agar tercapai sebuah tujuan; b) kepemimpinan sebuah tindakan mempengaruhi orang lain dengan cara petunjuk atau perintah; c) kepemimpinan tindakan yang menyebabkan orang lain bertindak atau merespon dan menimbulkan perubahan positif; e) kepemimpinan kemampuan untuk menciptakan rasa percaya diri dan dukungan diantara bawahan agar tujuan organisasional dapat tercapai dengan baijk.

Sedangakan pendapat Raharjo (2011:27) Pada umumnya komunikasi dilakukana dengan cara lisan dan verbal yang dapat dimengerti oleh dua belah pihak. Seorang pemimpin mampu mengarahkan masa, lawan bicara, audience, pemirsa, pengikut atau bawahan untuk melakukan hal-hal yang diinginkan, mempengaruhi, merubah, memerintah, memberdayakan orang-orang menggunakan cara-cara hypnosis. Dipertegas pendapat Sinamo (2000:146-151) pemimpin memiliki visi yang kuat dan mampu mengkomunikasikan visi itu agar dapat dilaksanakan dengan baik seperti; (a) memimpin dengan visi yang jelas, (b) memimpin dengan keteladanan, (c) seorang komunikator yang terampil (d) tenang menghadapi situasi-situasi yang sulit (e) mampu mengundang ketidak-sepahaman secara konstruktif, (f) tampil dengan citra professional, (g) mampu membuat masalah yang rumit menjadi sederhana, (h) mampu bekerja dan membangun keberhasilan bersama tim. 
Dilengkapi Yukl (2005:28) bahwa pemimpin manpu membangun jaringan dengan cara; (a) berbicara dengan orang lain setelah terjadi intraksi sosial organisasi; (b) melayani komite kelompok kepentingan dan gugugs tugas; (c)bergabung dengan pemuka masyarakat; (d) menghadiri pertemuan asosiasi profesional.

Pemimpin yang aktif dan kreatif, jika ia memiliki kemampuan personal membangun komunikasi sosial terhadap masyarakat dengan motivasi perubahan terhadap hal-hal yang positif. Hal ini relevansi dengan kutipan Suranto pendapat dari Stewart mendenifinisikan bahwa: "interpersonal coomunication in tersm of willingness to shere unique aspects of the self" yang artinya komunikasi interpersonal menunjukkan adanya kesediaan untuk berbagi aspek-aspek unik dari diri individu.

Kepemimpinan pada lembaga pendidikan didorong agar lebih aktif menjalankan komunikasi dengan stakeholder dan kaya ide juga agrisif yang berorientasi pada pengembangan mutu dalam bingkai kerapian administrasi yang mengarah kepada pelayanan terhadap siswa didik, hal ini disampikan Stronge (2013:121) berdasarkan hasil-hasil riset yang dilakukan oleh "Council Of Chief State School Officer" menetapkan enam standar yang mengidentifikasikan administrator sekolah adalah pemimpin pendidikan (kepala sekolah) yang mendorong kesuksesan seluruh siswa dengan Memfasilitasi adanya visi bersama, Membangun hubungan dengan keluarga siswa dan komunitas yang lebih luas, Bertindak secara adil dan beretika, Merespon memengaruhi politik, sosial, ekonomi, hukum dan kultur dalam konteks yang lebih luas.

Kepala sekolah cerdasa dalam bertindak dan bijak menetapkan sebuah keputusan jikalau ditopang oleh keahlian atau berdasarkan keilmuan hal ini disampaikan oleh Bungin (2011:246) seseorang yang ingin mencari kebenaran, bermula dari pendekatan scientific yang mengarah kepada pola komunikasi yang ideal, disamping itu juga perkuat oleh pendapat Schermerhorn (2011:206) "decision making is the process of choosing a course of action to deal with a problem or opportunity" Pengambilan keputusan sebuah proses dari memilih rangkaian tindakan berhubungan dengan masalah atau kesempatan.

Pemimpin memiliki tanggung jawab terhadap pengembangan sebuah organisasi yang dituntut bijak dalam membuat keputusan, adapun pengambilan keputusan dapat menggunakan model yang berbeda yakni model pengambilan keputusan terprogram dan tak terprogram (programmed and nonprogrammed decision). Kualitas seorang pemimpin salah satunya adalah kemampuan mengambil keputusan yang paling tepat dan bijaksana berdasarkan pertimbangan yang ada untuk mengatasi suatu masalah.

Perilaku seorang pemimpin sangat berpengaruh terhadap sebuah pengambilan keputusan. Hal ini dipengaruhi oleh nilai-nilai kecenderungan terhadap resiko, serta peningkatan komitmen meningkatkan kinerja, adapun untuk meningkatkan kinerja karyawan seorang pemimpin dituntut memiliki strategi dalam mengambil keputusan, hal ini ditegaskan oleh Bovee (2007:18) bahwa stratrgi komunikasi yang efektif akan memperbaiki kemampuan dasar yang menbuat umpan balik menjadi konstruktif yang mampu memberikan apresiasi terhadap bawahan. 
Pemberian penghargaan kepada karyawan akan menumbuhkan rasa memiliki serta rasa tanggung jawab yang besar untuk terus meningkatkan kinerjanya sehingga perusahaan atau suatu organisasi tersebut akan semakin maju dan berkembang. Intrinsic reward adalah completion, achievement, autonomy dan personal growth. Pemahaman dari completion adalah kemampuan untuk memulai dan menyelesaikan proyek atau pekerjaan bagi seseorang. Achievement atau prestasi adalah penghargaan terhadap keberhasilan diri yang diperoleh ketika seseorang meraih pencapaian yang menantang. Autonomy berarti bahwa setiap orang yang bekerja memperoleh hak dan hak istimewa untuk membuat keputusan dan menjalankannya tanpa pengawasan yang ketat.

Pemahaman dari personal growth adalahperkembangan diri seseorang dimana dengan memperluas kemampuannya akan mampu memaksimalkan atau setidaknya memuaskan potensi ketrampilannya. Extrinsic reward adalah financial rewards, interpersonal rewards dan promotion. Financial rewards yangpertama disebut sebagai salary dan wages atau penghargaan yang berujud uang antara lain yaitu gaji dan upah. Penghargaan finansial yang kedua adalah employee benefit atau tunjangan karyawan yang terdiri dari tunjangan pensiun, kesehatan atau rumah sakit, liburan. Interpersonal rewards atau penghargaan perseorangan dapat diperoleh dari seorang pimpinan atau manajer yang memiliki kewenangan untuk memberikan penghargaan perseorangan ini sebagai kedudukan atau pengakuan. Hal yang ketiga yang merupakan penghargaan ekstrinsik adalah promotion, dimana tidak setiap orang berkesempatan untuk memperolehnya.

Terkait tentang kepemimpinan tidaklah terlepas antara bawahan dan atasan dalam sebuah organisasi yang selalu bersinergi dalam pengembangan, organisasi akan berjalan dengan baik jika pemimpin loyal dengan bawahan menjalankan komunikasi pesuasif sebagai upaya memajukan dalam membangun relasi dengan stakeholder atau pihak-pihak terkait yang memiliki kontribusi positif terhadap kemajuan, sehingga seorang pimpinan dalam membuat kebijakan atau memutuskan untuk memberi penghargaan berupa kompensasi, rewads berupa promosi jabatan organisasi seyogianya untuk mengkaji lebih mendalam atas kewajaran antara hak seseorang dengan pekerjaannya.

\section{PEMBAHASAN}

\section{Berpikir realistis}

Kepala sekolah sebagai pemimpin akan mencermikan keteladanan, berpikir ralistis dalam menyikapi berbagai persoalan yang terjadi di lingkugan sekoalah dia mampu menilai dirinya kelebihan dan kekurangannya, baik secara fisik, mental, pengetahuan, juga keterampilannya. Kepemimpinan untuk melakukan relasi sosial dia berusaha untuk menyadari bahwa, menjadi pemimpin memiliki tanggung jawab penuh dalam pengembangan pendidikan yang dia kelola, sehinggga dia berusaha menjadi pemimpin yang berkarakter, pemimpin situasional, berbagai ujian dan tantangan dia berusaha tabah mengemban amanah, dia sadar apa yang dialaminya secara realistis, dia mau menerima secara wajar apapun yang terjadi dalam proses perjuangannya membangun dan mengembangkan pendidikan ke yang lebih baik dengan upaya kegiatan keliling mensosialisasikan lembaga yang dia kelola, ini adalah bagian dari kreativitas positif mewujudkan 
nilai keihlasan sebagai pondasi dasar pengembangan SMK-IC-NW yang ada berdiri di Batam 2013.

\section{Komunikasi Aktif}

Pemimpin mampu berintraksi sosial pada lingkungannya, mengembangkan ide kreatif yang mengantarkan pada keberhasilan menjaga visi yang telah ditetapkan, komunikasi dua arah jarang dilakukan antara kepala sekolah dengan bawahan (tenaga pendidik dan kependidikan), sementara komunikasi antarpesonal (interpersonal communication) merupakan langkah terbaik untuk mengawali proses pendidikan di sekolah sehingga dari berbagai sisi akan memiliki energi pengembangan yang berkesinambungan. Adapun pada SMK-IC-NW Batam yang berdiri pada tahun 2013 pengelolaanya kurang memadai ditinjau dari minat siswa dan dewan guru yang mengajar pada sekolah tersebut, saat ini 2018 jumlah siswa tercatan sebagai yaitu: (a) kelas sepuluh 07 orang siswa; (b) kelas sebelas 06 orang; (c) kelas duabelas 04 orang. Hal tersebut terjadi karena kepemimpinan kepala sekolah SMK-IC-NW kurang motivasi menjalankan tugasnnya yang disebabkan oleh faktor komunikasi organisasi yang bermasalah. Raharjo (2011:27) Pada umumnya komunikasi dilakukana dengan cara lisan dan verbal yang dapat dimengerti oleh dua belah pihak. Seorang pemimpin mampu mengarahkan masa, lawan bicara, audience, pemirsa, pengikut atau bawahan untuk melakukan hal-hal yang diinginkan, mempengaruhi, merubah, memerintah, memberdayakan orang-orang menggunakan cara-cara hypnosis. Dipertegas pendapat Sinamo (2000:146-151) pemimpin memiliki visi yang kuat dan mampu mengkomunikasikan visi itu agar dapat dilaksanakan dengan baik seperti; (a) memimpin dengan visi yang jelas, (b) memimpin dengan keteladanan, (c) seorang komunikator yang terampil (d) tenang menghadapi situasi-situasi yang sulit (e) mampu mengundang ketidaksepahaman secara konstruktif, (f) tampil dengan citra professional, (g) mampu membuat masalah yang rumit menjadi sederhana, (h) mampu bekerja dan membangun keberhasilan bersama tim.

Kepala sekolah sebagai pemimpin terdepan pada lembaga pendidikan yang sayogianya menyadari bahwa komunikasi mempunyai makna dan nilai yang tinggi, sehingia kepala sekolah sebagai visioner, inisiator, motivator dalam pengelolaan lembaga pendidikan, meningkatkan motivasi, profesionalisme guru dalam meningkatkan kinerja pendidik dan tenaga kependidikan. Keterbatasan kepala sekolah yang menjadi instrument kunci dalam pengembangan lembaga pendidikan dominan berdasarkan komunikasi manajemen pendidikannya berpengaruh terhadap proses belajar mengajar yang berdampak kepada minat belajar siswa. Yukl (2005:28) bahwa pemimpin manpu membangun jaringan dengan cara; (a) berbicara dengan orang lain setelah terjadi intraksi sosial organisasi; (b) melayani komite kelompok kepentingan dan gugugs tugas; (c)bergabung dengan pemuka masyarakat; (d) menghadiri pertemuan asosiasi profesional. Stephen P. Robin (2013:374-375) menyatakan bahwa interpersonal communication terdapat tiga jenis komunikasi yang dapat terjalin yakni oral communication, written communication and nonverbal communication.

Media komunikasi berupa buku panduan akademik merupakan media yang sangat efektif bagi siswa maupun orang tua dengan pihak sekolah. Berdasarkan salah satu wewenang kepala sekolah yang tertuang dalam buku panduan akademik bahwa sekolah menjalin relasi kemitraan 
kerja dengan pihak luar baik dari dalam negeri maupun dari luar negeri maka kinerja kepala sekolah SMK-IC-NW Batam selayaknya mendapatkan dari pihak-pihak terkait mengapreasi. "Tindakan kepala sekolah secara intens melakukan koordinasi serta komunikasi dengan seluruh jajaran pihak sekolah akan menunai hasil yang memuaskan" Stephen P. Robbins (2013:370) dalam bukunya menyatakan bahwa jalinan komunikasi memiliki 4 fungsi yakni ; kontrol, motivasi, ekspresi dan informasi.

\section{Pengambilan keputusan}

Tanggung jawab serta wewenang yang dimiliki, kepala sekolah merupakan pemegang hak dalam pengambilan keputusan. Wewenang kepala sekolah mengenai pemilihan staf kerja dan mengusulkan ke pihak Yayasan Islamic Center untuk pengesahan atau pengangkatan, mengadakan evaluasi staf untuk kenaikan jenjang kepangkatan/golongan kerja, memanggil dan memberikan teguran baik secara lisan maupun tertulis (surat peringatan) terhadap pegawai edukatif yang melanggar disiplin dan kode etik profesi sebagaimana telah digariskan oleh Yayasan Islamic Center merupakan pengambilan keputusan tipe programmed decisions. John M. Ivancevich (2014:401) mendefinisikan pengambilan keputusan, yaitu "decision making is defined as the process of choosing a particular action that deals with a problem or opportunity" Nonprogrammed decisions merupakan pengambilan keputusan yang diambil untuk mengatasi masalah manajemen yang unik dan komplek pada SMK-IC-NW Batam.

Berdasarkan penelitian ini yang telah berbentuk dalam katagori karya tulis ilmiah dengan harapan agar menjadi salah satu acuan untuk melakukan evaluasi dalam segala aspek di lingkungan sekolah. Berdasarkan observasi dan wawancara yang dilaksanakan peneliti, kepala sekolah seagai objek, visi dan misi pengelolaan sekolah yang professional diharapkan melekat pada nilai-nilai kepemimpinannya untuk mendapatkan capaian yang maksimal, sehingga manajemen pendidikan dikondisikan berdasarkan ruang dan waktu, membuka peluang terhadap pengelolaan yang berkemajuan.

\section{Pemberian penghargaan}

Kepala Sekolah memiliki wewenang memberikan penghargaan terhadap bawahannya yang akan menumbuhkan rasa tanggung jawab yang besar untuk terus meningkatkan kinerj dalam menjalankan profesinya sebagai guru pada sekolah SMK-IC-NW dengan tujuan sekolah yang dipimpinnya akan semakin maju dan berkembang. John M. Ivancevich (2014:179) menyatakan bahwa tujuan utama dari pemberian penghargaan adalah : (1) memikat orang yang ahli untuk bergabung dengan organisasi, (2) menjaga karyawan untuk datang bekerja, dan (3) memotivasi karyawan meraih kinerja dengan level yang tinggi. Kemudian diadakan evaluasi unjuk kerja yang akan mewujudkan kepuasan yang dipengaruhi oleh intrinsic reward dan extrinsic reward. Kompensasi merupakan upaya konkrit sebagai penghargaan yang utama yaitu berdasarkan gaji perbulan yang diterima dan adanya tunjangan transportasi, dan tunjangan hari raya, serta tunjangan kesehatan.

\section{SIMPULAN:}

1. Kepala Sekolah sebagai motivator yang berpikir realistis dalam menjalankan tugas dengan ditopang oleh kemampuan berkomunikasi aktif untuk memprovokasi masyarakat dan mampu mempengaruhi kerangka berpikir orang lain sehingga orang tersebut bersedia 
mengikuti saran-saran atau himbauannya untuk turut serta dalam penyelenggaraan pendidikan yang dipimpin. Visi kepala sekalah mustahil akan terjadi tanpa kemapuan dan keterampilan komunikasi yang baik, sesuai dengan konsep bahasa bijaksana adalah memiliki proses pesan yang terfokus pada begaimana orang-orang menyampaikan, menginterpretasi, mengevaluasi perilaku, dan mampu pada tataran proses produksi pesan yang terfokus komunikasi dalam rangka intraksi sosial dengan tercapainya tujuan bersama.

2. Penerapan sistem interpersonal communication merupakan langkah terbaik untuk mengawali proses pendidikan disekolah. Dengan memperhatikan komunikasi dilakukan antarguru, dan antarorang tua dengan kepala sekolah kurang terjalin dengan intens yang menyebabkan kesenjangan komunikasi intraaktif persuasive sehingga emosional kekeluargaan menjadi renggang. Sosial komunikasi merupakan hal penting untuk mewujudkan visi pengembangan pendidikan yang kondusip (Social networking and electronic communication) merupakan bentuk komunikasi yang dimanfaatkan dalam meningkatkan potensi kearifan lokal yang merupakan budaya sosial pendidikan nasional terintegrasi. Bentuk komukasi berikutnya adalah written communication, media komunikasi berupa buku panduan akademik dan buku harian (aktivitas siswa di dalam dan di luar lingkungan sekolah) merupakan media yang sangat efektif bagi siswa maupun orang tua dengan pihak sekolah. Potensi kepala sekolah terdapat pengaruh tinggi untuk melakukan peningkatkan minat belajar siswa dan minat masyarakat berkerjasama membangaun serta mengembangkan SMK-IC-NW yang kurang mendapat respond positif saat ini, karena kepala sekolah memiliki keilmuan yang luas dibidang agama, dengan nilai-nilai spritiual akan mampu menciptakan pola pikir seseorang, kesadaran pentingnya ilmu pengetahuan yang disingkronisasikan antara disiplin ilmu umum dan agama.

3. Kepemimpinan kepala sekolah SMK-IC-NW, dengan tanggung jawab penuh meningkatkan mutu pendidikan dari berbagai aspek, terutama meningkatkan motivasi tenaga pendidikan berdasarkan kompensasi yang memadai sehingga terjalin keserasian meningkatkan profesionalisme guru terhadap kinerja guru yang akan sadar dengan tanggung jawab menciptakan pendidikan yang bermutu, sehingga masyarakat terwujud nilai-nilai loyalitas untuk membangun dan mengembangkan pendididkan yang menjadi sentral utama mencerdaskan generasi bangsa pada lingkungannya. Kepala sekolah yang kereatif jikalau mampu menciptakan Programmed decisions dilaksanakan berdasarkan tanggung jawab serta wewenang yang dimiliki, mengadakan evaluasi kerja staf, memberikan teguran baik secara lisan maupun tertulis jika melanggar disiplin dan kode etik profesi yang telah ditetapkan oleh Yayasan Islamic Ceter Nahdlatul Wathan (YIC-NW).

4. Kepala sekolah SMK-IC-NW cerdas memberikan penghargaan terhadap bawahan jika memiliki kemampuan dan keahlian dalam bidangnya untuk meningkatkan kemajuan sekolah (academic and humaniora award) sebagai proses motivasi untuk mengerahkan segala daya untuk menciptakan unjuk kerja individu yang dipengaruhi oleh kemampuan, ketrampilan dan pengalaman, sebgai upaya peningkatan mutu pendidikan pada SMK-IC-NW, dengan munculnya didikasi tinggi para guru yang mengajar, samangat dan tanggung jawab yang 
besar untuk meningkatkan prestasi kerjanya maka SMK-IC-NW akan merkembang baik sesuai harapan masyarakat yaitu mengidolakan pendidikan yang berkarakter dan terintegrasi.

\section{SARAN:}

a. Penelitian kualitatif studi kasus yang berfokus pada kepemimpinan kepala sekolah diperlukan peneliti yang lain untuk dikembangkan. Dalam ruang lingkup kepemimpinan kepala sekolah terus berkembang sesuai perkembangan zaman yang dipengaruhi oleh perkembangan sosial, politik dan budaya masyarakat serta pengaruh kebijakan-kebijakan pemerintah dibidang pendidikan formal.

b. Secara implisit kepemimpinan kepala sekolah SMK-IC-NW agar komitmen menjadikan lingkungan sekolah berseri belum tercapai dengan optimal, dikarenakan kurangnya komunikasa aktif antara kepala sekolah dengan dewan guru, yang menyebabkan lingkungan sekolah belum tertata dengan baik dan terintegrasi berdasarkan setandar pendidikan nasional yang telah ditetapkan oleh pemerintah.

\section{DAFTAR PUSTAKA:}

Armstrong, Michael. Armstrong's Handbook of Management and Leadership. London: Kogan Page, 2009.

Andrew J. Dubrin, The Complete Ideal's Guides: Leadership (alih bahasa, Tri Wibowo), (PT. Fajara Interpratama Offset, Jakrta-Pradana, 2009

Bungin Burhan, Sosiologi Komunikasi, Jakarta: PT. Kencana, 2011

Creswell. W. John, Reserch Design, Qualitative, Quantitative and Mixed Methods Approaches, Thousand Oaks California, 2009.

Colquit, Jason A. Jeffery A. Lepine, dan Michael J. Wesson, Organizational Behavior. McGrawHill- Irwin, 2009.

Dewett, Todd. The Little Black Book of Leadership. Dayton: TVA, 2010.

Greene, John O. and Brant R. Burleson, Handbook Of Communication And Social Interaction Skills, (Lawrence Erlbaum Associates, Publishers, 2003.

Ivancevich, John M., Robert Konopaske dan Michael T. Matteson, Organizational Behavior and Management 10th edition. New York: McGraw-Hill, 2014.

Nelsen, Debra L. James Campbell Qick, Organizational Behavior. South Western: Thomson, 2006

Raharjo Ridwan, Now The Ability is Yours Leadership Hypnosis - Influencing Altring Commanding Empowering Effectivily, Yogyakarta: Pohon Cahaya, 2011

Sogono Dedy dkk, Kamus Besar Bahsa Indonesia Pustaka Bahasa, Jakarta: PT. Gramedia Pustaka Utama 2008.

Schermerhorn, John R. et al., Organizational Behavior. New York: John Wiley \& Sons Inc., 2011

Stronge, James H., Holly B. Richard dan Nancy Catano, Kualitas kepala Sekolah yang efektif, terjemahan oleh Siti Mahyuni. Jakarta : PT Indeks Permata Puri Media, 2013.

Yukl Garry, Kepemimpinan Dalam Organisasi, Alih Bahsa; Suprianto Budi, Jakarta: PT Indeks, 2005

Yin, Robert K. Case Study Research: Design and Methods, Forth Edition. Colorado: Westview Press, 2002 
Historia: Jurnal Program Studi Pendidikan Sejarah

Vol 2. No 1 (2017): 40-53

P-ISSN 2301-8305

E-ISSN 2599-0063

Sukamdinata, Nana Saodih. Metodologi Penelitian Pendidikan. Bandung: Remaja Rosdakarya, 2002. 